\title{
O GENOCÍDIO ARMÊNIO NO DIREITO INTERNACIONAL
}

\author{
THE ARMENIAN GENOCIDE IN INTERNATIONAL LAW
}

\author{
Marco Aurelio Moura dos Santos* \\ Erico Lima de Oliveira** \\ Victor Antonio Del Vecchio ${ }^{* * *}$
}

\begin{abstract}
Resumo:
Aborda-se o evento do genocídio armênio, ocorrido no contexto histórico da Primeira Guerra Mundial e a posterior contribuição para construção do conceito no Direito Internacional. O termo "genocídio" é atribuído ao jurista polonês Raphael Lemkin, que também garantiu que o conceito formulado se tornasse amplamente divulgado e reconhecido como um crime cuja repressão e punição estariam amplamente asseguradas no Direito Internacional. Existem inúmeras narrativas sobre o fenômeno genocídio e embora não seja prática atual, foi no contexto histórico das grandes guerras do Século XX e dos consequentes extermínios em massa, que a questão se tornou central para a sociedade internacional. Diante desses fenômenos, questionou-se o que vem a caracterizar o genocídio e quais são os mecanismos de proteção internacional que possam coibir, atualmente, a prática deste crime. Esta pesquisa terá por objetivo geral analisar a sistematização histórica a justificar a conceituação do genocídio nas normas internacionais. Problematiza-se, porém, o papel histórico de tais fenômenos para a configuração dos crimes internacionais.
\end{abstract}

Palavras-chave: Genocídio. Direito Internacional. Tratados de Paz. Primeira Guerra Mundial. Direito Internacional Penal.

\begin{abstract}
:
This paper is about the Armenian genocide, which occurred in the historical context of the World War I and the subsequent contribution of this event for the construction of the concept in International Law. The term "genocide" is attributed to the Polish jurist Raphael Lemkin, who also ensured that the concept formulated became widely publicized and recognized as a crime whose repression and punishment would be widely ensured in International Law. There are numerous narratives on the genocide phenomenon and although it is not current practice, it was in the historical context
\end{abstract}

\footnotetext{
Doutorando em Direito Internacional pela Universidade de São Paulo/USP. Mestre em Direito da Sociedade da Informação pelo Centro Universitário das Faculdades Metropolitanas Unidas - FMU/SP. Especialista em Direito Público pela Escola Paulista da Magistratura TJ/SP. Graduado em Direito pelo Centro Universitário das Faculdades Metropolitanas Unidas - FMU/SP. Docente do Curso de Direito do Centro Universitário das Faculdades Metropolitanas Unidas - FMU/SP. Pesquisador do GEPIM Grupo de Estudos sobre a Proteção Internacional de Minorias - Faculdade de Direito da Universidade de São Paulo.

** Doutorando em Direito Internacional pela Universidade de São Paulo/UPS. Mestre em Direito Internacional pela Universidade de São Paulo. Graduado em Direito pela Universidade Federal do Pará. Defensor Público Federal de $1^{\mathrm{a}}$ categoria - Defensoria Pública da União.

*** Graduado em Direito pela Universidade de São Paulo/USP. Pesquisador do GEPIM Grupo de Estudos sobre a Proteção Internacional de Minorias - Faculdade de Direito da Universidade de São Paulo. Advogado e Coordenador do Programa de Promoção dos Direitos de Migrantes (ProMigra/FDUSP).
} 
of the twentieth Century wars and mass exterminations that the issue became central to international society. Faced with these phenomena, what has come to characterize genocide and which are the mechanisms of international protection that can curb the practice of this crime currently. This research will have as general aim to analyze the historical systematization to justify the conceptualization of genocide in International Law, despite of the problematic historical role of such phenomena in the configuration of international crimes.

Keywords: Genocide. International Law. Peace Treaties. World War I. International Criminal Law.

Introdução

O Genocídio Armênio, acontecimento considerado como uma das primeiras grandes catástrofes do século XX, pode ser denominado como principal episódio da civilização armênia, trazendo impactos para essa até os dias atuais, e sendo importante fonte para o desenvolvimento do Direito Internacional Público. O genocídio não é uma prática atual. A História foi marcada por massacres e atrocidades dos mais diversos tipos. Todavia, na atualidade, houve uma tipificação específica. As práticas da Alemanha nazista, do Holocausto, chocaram a sociedade internacional e causaram uma repulsa tão grande que as nações se preocuparam em criar mecanismos de prevenção desse crime, porém o crime de genocídio ainda persiste, sendo veiculadas, não raramente, notícias de populações dizimadas brutalmente. Diante desses fenômenos, questionou-se o que vem a caracterizar o genocídio e quais são os mecanismos de proteção internacional que possam coibir, atualmente, a prática deste crime. Após o final da Segunda Guerra Mundial, os indiciamentos e os julgamentos de ocorridos em Nuremberg, referiram-se ao "genocídio" no contexto de crimes contra a humanidade, particularmente em relação aos crimes de perseguição e homicídio. No entanto, o genocídio não era um crime separado na Carta do Tribunal Militar Internacional (Carta de Nuremberg) e foi utilizado como um termo empregado para descrever um fenômeno e não exatamente um tipo penal. A codificação do termo enquanto um crime independente, no direito internacional, ocorre na Convenção de Prevenção e Repressão do Crime de Genocídio de 1948 (mais conhecida como Convenção sobre Genocídio). De acordo com o art. $1^{\circ}$ da Convenção, as partes confirmam o genocídio, seja este cometido durante tempo de paz ou guerra, um crime sob o Direito Internacional, ao qual se comprometem a prevenir e reprimir.

A perpetuação de atrocidades contra a humanidade, tais como o genocídio, trata-se de fenômeno evidente na contemporaneidade, mesmo com a existência de regras jurídicas e sociais que buscam preveni-las e combatê-las. A utilização do termo "genocídio" é precisa do ponto de vista legal, porém inclui um elemento de difícil comprovação, a "intenção". Há inúmeras narrativas em torno do termo genocídio e a 
discussão acadêmica é vasta e não um termo unívoco diante de tais abordagens. Existem abordagens históricas, sociológicas, psicanalíticas, filosóficas e jurídicas. Há, ainda, um intenso debate nos meios de comunicação e na mídia em geral. Nessa pesquisa discute-se a definição de genocídio no campo jurídico, em especial na identificação do fato histórico ocorrido com os armênios no desmantelamento do Império Otomano no contexto anterior à Primeira Guerra, bem como durante ao conflito armado ocorrido entre os anos de 1914 a 1918.

\section{Contexto Histórico}

Para entender o Genocídio Armênio, é necessário primeiramente situá-lo no tempo e espaço, mais precisamente, situar a comunidade armênia vitimada.

Os armênios são uma civilização milenar, com língua e alfabeto próprios, e uma organização social muito antiga a qual já os distinguia entre os povos que habitavam o sul do Cáucaso. Estão localizados em uma região estratégica, a Eurásia, que liga os continentes europeu, em sua porção oriental, e asiático em sua porção ocidental, o que faz com que as extensões de terra por eles ocupadas fossem cobiçadas e, por vezes invadidas e conquistadas por outros povos, tais como os assírios, gregos, romanos, bizantinos, árabes, mongóis, persas, otomanos e russos. Isso promoveu uma alternância de períodos em que os armênios desfrutavam de maior liberdade, enquanto Estado, e outros, em que havia submissão.

Outro ponto chave para entendermos o genocídio, é a devoção religiosa dos armênios. Logo após o surgimento do cristianismo, a região começou a abrigar diversas comunidades cristãs que lá se refugiavam em razão da tolerância e posterior simpatia que havia quanto a ela. Isso contribuiu para que a religião se espalhasse, inclusive promovendo a conversão de pagãos da região. Em 301 d.C. o Reino da Armênia consagra-se como a primeira nação a adotar o cristianismo como religião de Estado (CASELLA, 2014, p. 586), dez anos antes do Edito de Milão ser emitido, em 313 d.C., declarando tolerância religiosa no Império Romano. No século IV é criada a Igreja Apostólica Armênia, outro fator de distinção.

Com a ascensão do Império Otomano, a Armênia foi sendo englobada por esse, de religião islâmica e população étnica e linguisticamente distinta. Assim, podemos entender os armênios à época do Genocídio, enquanto minoria étnica, linguística e religiosa que habitava e integravam o Império Otomano.

Sua antiga organização social e valorização da erudição, bem como a tradição no trabalho com manufaturas e comércio, por vezes articulados com outras comunidades armênias pulverizadas ao longo do Império Otomano, fez com que muitos desses cidadãos, no fim do século XIX e início do XX, ocupassem posições de poder, 
seja pelo prestígio de suas profissões, como a de médicos, engenheiros, arquitetos, seja pelo status econômico advindo de suas produções e práticas comerciais. No cenário de integração que havia com a sociedade otomana e, já visando vantagens demográficas, políticas e econômicas, eram frequentes requisições de jovens armênios para integrar as forças armadas do Império. Esses eram, via de regra, demandados em maior contingente proporcional do que as populações com identidade étnica, cultural e religiosa otomana. Também não raro, os armênios ofereciam aportes financeiros em troca de parte dos contingentes exigidos. Essa política denota um caráter nacionalista que já era desenvolvido pelas autoridades otomanas, e também uma preocupação com os armênios distinta de outras etnias: eles habitavam uma grande extensão da Anatólia, o coração do Império Otomano, assim, permitir seu fortalecimento demográfico e nacional poderia dar margem a uma luta por independência, o que significaria uma ruptura territorial crítica. Nessa mesma linha, de discriminação e frenagem do desenvolvimento armênio, era aplicado regime tributário diferente do conferido aos turcos.

No ano de 1877 irrompe a Guerra Russa-Otomana, na qual os primeiros buscavam acesso ao Mar Mediterrâneo e a anexação da Península Balcânica, então sob domínio otomano. Com um grande custo financeiro e humano para ambos os lados, a Rússia aceita trégua no início de 1878. Como saldo desse conflito, para análise do principal evento tratado neste artigo, podemos destacar a perda de territórios otomanos nos Balcãs, um impacto econômico na já debilitada saúde financeira turca, e a celebração do Tratado de Berlim, que dentre diversas diretrizes, estabelecia certo controle de potências europeias na administração interna do Império Otomano, e a garantia de direitos, sobretudo de liberdade religiosa, às suas populações, salientada já a necessidade de proteção específica aos armênios.

No final do século XIX, mais precisamente entre os anos de 1894 a 1896, os armênios fazem manifestações pelo não pagamento de impostos abusivos às autoridades otomanas, que reprimem com violência desproporcional os manifestantes, promovendo uma série de agressões que inaugurou "Os Massacres Hamidianos", em referência à Abdul Hamid II, sultão ${ }^{1}$ conhecido como "O Grande Sangrador" (CASELLA, 2014, p. 577), justamente em função da violência imposta em muitas de suas decisões de governo. Tal feito seria posteriormente perdoado pela comunidade armênia, a qual, juntamente a representantes turcos, promoveu cerimônias de perdão no ano de 1908.

Porém, não muito mais tarde, no ano de 1909 ocorre o "Massacre de Adana", o segundo na série de massacres em larga escala contra a população armênia, ${ }^{2}$

Líder político do Império Otomano e, no caso, também califa, líder espiritual dos muçulmanos.

ADALIAN, Rouben Paul. Adana Massacre. In: ENCYCLOPEDIA Entries on the Armenian Genocide. Armenian National Institute. Washington - DC, 2005. Disponível em: $<$ http://www.armenian-genocide.org/ 
que nesse episódio apoiou as forças revolucionárias capitaneadas pelos "Jovens Turcos", as quais visavam depor o Sultão Adbul Hamid II e restaurar a constituição por ele suspensa em 1878, o que acabaria assim por conferir aos armênios maior status de igualdade em relação aos turcos islâmicos. A repressão pelas forças hamidianas foi brutal e promoveu a morte de 20 mil a 30 mil armênios, muitos dos quais pertencentes às classes econômicas mais abastadas dessa comunidade. Os ataques não consistiam apenas em execuções, mas também eram destruídos e confiscados muitos bens, tais como animais, máquinas agrícolas entre outros tipos de maquinário. Logo depois desse episódio que ocorreu em conturbado período em que os "Jovens Turcos" tentavam consolidar o golpe de Estado que depôs o sultão, esses cristalizam-se a frente do governo do Império Otomano.

Entre 1912-1913 irrompem as Guerras Balcânicas, que significaram nova perda de territórios otomanos e um alto custo econômico de guerra. Com essa diminuição de territórios a oeste, os turcos focam sua política no fortalecimento da parte asiática, e ganha força a ideologia de uma oligarquia militar que tende ao fundamentalismo, fomentada pelas bandeiras do "Panturquismo" e "Turquia para os turcos" (CASELLA, 2014, p. 572), e que visava a regeneração do Império e sua transformação num EstadoNação considerado moderno. (KÉVORKIAN; DUCLERT; BOZARSLAN, 2015, p. 17). Essa exaltação nacionalista dava margem para conflitos inclusive entre as populações civis armênia e turca, sobretudo se considerado que muitos indivíduos dessa primeira tiveram de ser realocados para dar espaço a turcos refugiados dos territórios balcânicos perdidos. Eram décadas de grave crise, que seguiam desde os governos hamidianos, marcados por corrupção e ineficiência administrativa, e depois agravavam-se com a diminuição do território otomano, na atual Grécia e nos Bálcãs, além da derrocada econômica. A situação chegara a tal ponto que os europeus referiam-se ao Império Otomano como seu "homem doente". (CASELLA, 2014, p. 588).

Em 1914, uma sucessão de acontecimentos ${ }^{3}$ leva os “Jovens Turcos" a declarar guerra à Entente e, assim, o massacre logo recomeçaria de maneira mais profunda e cruel. O governo otomano, sob alegação de "estado de guerra" e suspeitas de

adana.html>. Acesso em: 23 jun. 2017. "Adana Massacre was the second series of large-scale massacres of Armenians to break out in the Ottoman Empire. The atrocities committed in the province of Adana in April 1909 coincided with the counter-revolution staged by supporters of Sultan Abdul Hamid (Abdulhamit) II (1876-1909) who had been forced to restore the Ottoman Constitution as a result of the 1908 Young Turk Revolution led by the Committee of Union and Progress (CUP). A prosperous region on the Mediterranean coast encompassing the old principality of Cilicia, once an independent Armenian state between the eleventh and fourteenth centuries, the province of Adana had been spared the 1890's massacres".

3 O assassinato do arquiduque Francisco Ferdinando, herdeiro do trono da Áustria-Hungria, foi o estopim da Primeira Guerra Mundial, após este evento potências se mobilizaram, invocando suas alianças e colônias. Em poucas semanas, diversas nações estavam em guerra num conflito que se espalhou por quase todo planeta. 
colaboração com os adversários russos, coloca em prática seu plano de limpeza étnica, que visava varrer a civilização armênia de seu território, plano esse que já permeava a mentalidade dos governos turcos há décadas, tendo, inclusive, sido atribuída ao Sultão Abdul Hamid II a frase: "o único modo de se livrar da questão armênia é se livrar dos armênios”. (BRYCE, 1987 apud CASELLA, 2014, p. 577). Assim, estaria assegurado o domínio sobre as extensões territoriais que eles ocupavam, seria eliminado um potencial rival interno em tempos de uma guerra sem precedentes e o projeto nacional "panturquista" resultaria fortalecido. Nele uma minoria de diferente etnia, idioma e religião não tinha espaço, sobretudo porque ocupava espaços de poder e influência, e com o infeliz histórico de massacres promovidos pelos turcos.

Em 24 de abril de 1915, data em que é historicamente relembrado o início do Genocídio Armênio, a elite intelectual e política armênia de Constantinopla, capital do Império Otomano, foi presa. Sob tortura, as autoridades turcas obtiveram confissões de tramas de um golpe articulado com os Russos, procedendo à execução dos torturados após os relatos. Com o cenário então montado, o governo otomano ordena a deportação de toda população armênia.

Soldados armênios do exército otomano são desarmados e movidos para batalhões de trabalho e, novamente sob alegações de que "falavam em golpe contra o governo turco", são executados. O governo imperial inicia uma grande operação na qual confisca bens e terras, promove a islamização forçada (BAGHDJIAN, 1987 apud CASELLA, 2014, p. 566) e separa dos agrupamentos armênios os homens em idade de combate, entre 16 e 60 anos, para, em seguida, executá-los. (KÉVORKIAN; DUCLERT; BOZARSLAN, 2015, p. 19). Logo após os turcos ordenam a remoção dos idosos, crianças e mulheres, que foram obrigados a se deslocar a pé por longas distâncias em regiões pouco habitadas e por vezes áridas, escoltados por policiais turcos. Nesse percurso, elucida Casella, "São atacados, pilhados e mortos, por bandos de curdos, os tcheté, pelos próprios policiais ou pela população dos locais onde passavam”. (CASELLA, 2014, p. 591). Os que não eram mortos por forças humanas, em geral morriam em função da "política deliberada de exaustão e destruição das mulheres, crianças e velhos, arrastados de um lado para outro, em condições desumanas - algo como os campos de concentração nazistas, a céu aberto e em deslocamento". (BAGHDJIAN, 1987 apud CASELLA, 2014, p. 592).

Esse processo deixou um saldo estimado de 1,5 milhão de vítimas (KÉVORKIAN; DUCLERT; BOZARSLAN, 2015, p. 21), o que correspondia a dois terços da população armênia, sendo estimado que desses dois terços, ao menos um tenha sido sumário nos locais de origem e proximidades. Muito embora o Império Otomano tenha, ao longo de sua existência, oscilado em relação à rigidez da restrição de liberdades e direitos das minorias que o compunham e tenha, inclusive, praticado outros massacres contra elas, como contra os sírios, búlgaros, curdos, gregos e cristãos em geral, nenhum 
desses ocorreu em igual escala e com igual planejamento e execução como o praticado contra os armênios.

Apenas um terço de sua população total sobreviveu, e entre estes sobreviventes, a esmagadora maioria escapou da morte por circunstâncias fortuitas. $\mathrm{Na}$ Anatólia, algumas deportações foram feitas por via férrea, direto para campos de concentração montados nos pontos de interrupção ferroviária, os quais serviriam de estadia temporária até a saída efetiva dos domínios otomanos. Os campos dispunham de condições desumanas e muitas mortes neles ocorreram, porém, essas deportações por trens evitavam, em parte, o deslocamento a pé que vitimou uma grande parte dos armênios, a tal ponto que muitos conseguiram de fato deixar o Império Otomano e emigrar. Cabe notar ainda, que a cidade de Van, na Anatólia Oriental, densamente povoada por armênios, ofereceu resistência ao exército otomano num cerco de mais de um mês e, logo após esse, foi conquistada pelo exército russo, fato que impediu a aniquilação e a deportação da população armênia local. Há também relatos de jovens que eram raptadas durante o trânsito para exploração de mão de obra doméstica e sexual. Muitos armênios de Constantinopla também conseguiram escapar, e há inclusive relatos de que os próprios turcos, por vezes, facilitavam a fuga de armênios. Houve casos em que oficiais do governo otomano se negaram a cumprir ordens de execução e deportação, o que também permitiu com que alguns desses armênios que seriam vítimas, escapassem com vida.

Em agosto de 2016, após esse longo, cruel e sistemático processo de limpeza étnica, com a população armênia praticamente dizimada dos territórios otomanos e os processos de deportação e execuções concluídos, são liquidados os campos de concentração criados ao longo do Eufrates. $\mathrm{O}$ mundo assistira ao que muitos consideraram "a primeira grande tragédia do século XX".

\section{Momentos do Genocídio Armênio.}

- 24 de abril de 1915 - data inicial do genocídio - elite intelectual e política de Constantinopla é presa.

- $1^{\circ}$ Momento: maio a julho (1915) assassínio e deportação dos armênios que habitavam as sete províncias orientais da Anatólia;

- $2^{\circ}$ Momento: agosto de 1915 a janeiro de 1916, deportação dos armênios das demais províncias da Anatólia e da área europeia da Turquia;

- $3^{\circ}$ Momento: agosto de 1916, liquidação dos campos de concentração, escalonados ao longo do Eufrates. (CASELLA, 2014, p. 568). 
3. Tratados de Paz e o Genocídio Armênio.

Com fim da I Guerra Mundial em 1918 marca a derrota do Império Otomano e a Tríplice Aliança. Os países beligerantes se puseram então a negociar as rendições e os espólios do grande conflito. Assim, os tratados de paz tiveram lugar em várias partes do mundo e em diferentes momentos, cada qual tratando de interesses distintos. (ZAGNI, 2013, p. 130).

\subsection{Tratado Brest-Litovsk - 1918}

Em março de 1918, a Rússia Soviética negociou em Brest-Litovsk (Bielorrússia) com os Impérios Alemão, Austro-Húngaro, Otomano e a Bulgária. A jovem república, surgida na Revolução de Outubro de 1917 na Rússia, assina o tratado de BrestLitovsk com os impérios centrais e com isso, deixa os combates na frente leste. Mas a Rússia perde grande parte de seus territórios ocidentais para a Alemanha (Polônia, países bálticos e Finlândia, em particular) e mais de 30\% de sua população. Nessa oportunidade, a Rússia aceitou evacuar as regiões de Batum, Kars e Ardahan e o restante da Anatólia ocupada, devolvendo as terras aos turcos. Neste contexto a Armênia compunha o Comitê Transcaucasiano, com Geórgia e Azerbaijão. (ZAGNI, 2013, p. 130). A união era uma tentativa dos três países fortalecerem suas aspirações e negociações que aconteciam. Em 28 de maio de 1918, o Comitê sucumbiu e a Armênia se declarou um Estado independente, tendo como território nacional a chamada "Armênia Turca" e uma parte de seis vilayets (comunidades que detinham alguma autonomia administrativa) que compunham o Império Otomano e foram palco do Genocídio.

A Primeira República da Armênia, foi um estado nacional na região do Cáucaso, primeiro estabelecimento moderno de uma república armênia. O colapso do império czarista russo depois da Revolução Russa de 1917, permitiu que a Federação Revolucionária Armênia criasse uma nova república. Em 1918, a jovem república enfrentou o Império Otomano, durante a Campanha do Cáucaso, que concluiu com o Tratado de Batum. Com a derrota do Império Otomano no fim da Primeira Guerra Mundial, o presidente americano Woodrow Wilson propôs, na Conferência de Paz de Paris (1919), expandir as fronteiras da República da Armênia para que incluíssem regiões historicamente armênias, que passaram a ser conhecidas como "Armênia Wilsoniana" - o que foi ratificado posteriormente pelo Tratado de Sèvres. No entanto, o Tratado de Sèvres (1920) não chegou a ser cumprido uma vez que foi substituído pelo Tratado de Lausanne (1923).

Com o término da I Guerra Mundial e a derrota do Império Otomano e a Tríplice Aliança, os países beligerantes iniciam negociações sobre as rendições e espólios 
do grande conflito, neste contexto os tratados de paz tiveram lugar em várias partes do mundo e em diferentes momentos, cada qual tratando de interesses distintos. A questão armênia não deixou de ser afetada por estas negociações.

\subsection{Tratado de Sèvres (1920)}

O Império Otomano, aliado da Alemanha durante a Primeira Guerra Mundial, assina em 10 de agosto de 1920 a paz em Sèvres (Hauts-de-Seine). Os Aliados impõem um desmembramento do Império Otomano, cujo território fica reduzido à Anatólia, ou península anatoliana, uma região do extremo oeste da Ásia que corresponde hoje à porção asiática da Turquia, em oposição à porção europeia, a Trácia. O Tratado de Sèvres, que desmantela o Império Otomano, restou rejeitado pelos nacionalistas turcos liderados pelo general Mustafa Kemal Atatürk, que continua combatendo armênios, gregos e franceses. (ZAGNI, 2013, p. 130). Este tratado mostrou-se duro demais e impraticável, o que despertou a ação dos nacionalistas turcos que se negaram a aceitá-lo, passando a defender a independência da Turquia. Em resposta a tal partilha surge a figura do mito nacional Mustafa Kemal Pasha, logo renomeado Atatürk (Pai dos Turcos), mobilizando o nacionalismo turco e reorganizando parte do extinto exército otomano na Anatólia. Vitorioso na luta da independência, que resultou na expulsão das forças aliadas, Atatürk funda a República da Turquia em 1922, tornando-se seu primeiro presidente. Muda o nome de Constantinopla para Istambul e transfere a capital para Ancara, no centro do país, além de extinguir os vestígios do sultanato otomano ao exilar o último sultão. Graças às suas vitórias militares, o novo homem forte da Turquia impõe um novo tratado aos aliados que será firmado em Lausanne, em 24 de julho de 1923. (ZAGNI, 2013, p. 130).

O Tratado de Lausanne de 1923 reconheceu a Turquia em suas atuais fronteiras. Há um Acordo entre Grécia e Turquia, também assinado em Lausanne, em 30 de janeiro de 1923, que estabelecia troca de população entre os dois países, com remoção compulsória a começar em $1^{\circ}$ de maio do mesmo ano (ao menos 1,3 milhão de gregos abandonam a Ásia Menor, e cerca de 500 mil turcos partem da Grécia). (ZAGNI, 2013, p. 130).

O Tratado de Paz firmado em Sèvres tinha como partes os aliados (Império Britânico, França, Itália e Japão) e Associados e a Turquia e Associados: Armênia, Bélgica, Grécia, Hejaz (hoje Arábia Saudita), Polônia, Portugal, Romênia, Estado Sérvio-CroataEsloveno e Tchecoslováquia. 


\section{Especificidades:}

- Especificidade com não muçulmanos.

- Conversões ao Islã, a partir de $1^{\circ}$ de novembro de 1914 , canceladas a menos que optem voluntariamente e sejam feitas as formalidades necessárias;

- Assistência do governo para procurar desaparecidos (presos, internados, ou demais casos sob responsabilidade do governo), desde $1^{\circ}$ de novembro de 1914;

- Comissões mistas para ouvir vítimas ou familiares; Reconhecimento de nulidade de lei de 1915 que revogava propriedades, retorno de não turcos aos seus lares, devolução de bens;

- Comissões arbitrais com representantes do governo, representantes das comunidades minoritárias e representantes do Conselho da Liga das Nações;

- Garantia de imunidades eclesiásticas às minorias;

- Regiões com população considerável de judeus ou cristãos - respeito ao dia de descanso.

O Tratado de Sèvres previa a responsabilidade em relação aos massacres e a entrega dos responsáveis:

Art. 230 - O Governo turco compromete-se a entregar aos Poderes Aliados as pessoas cuja rendição pode ser exigida por este como responsável pelos massacres cometidos durante a continuação do estado de guerra em território que fez parte do Império Turco em 1 de agosto de $1914 .^{4}$

Havia ainda a previsão de que os Poderes Aliados reservar-se-iam ao direito de designar o tribunal que deve julgar as pessoas assim acusadas, e o Governo turco compromete-se a reconhecer esse tribunal. No caso de a Liga das Nações ter criado com tempo suficiente um tribunal competente para lidar com os referidos massacres, os Poderes Aliados também teriam o direito de encaminhar as pessoas antes desse tribunal, e o Governo turco se comprometera igualmente a reconhecer tal tribunal.

4 SÈVRES Traité de (10 août 1920). In: ENCYCLOPAEDIA Universalis. Disponível em: < http://www. universalis.fr/encyclopedie/traite-de-sevres/>. Acesso em: 18 jun. 2017. 


\subsection{Tratado de Lausanne}

Em 24 de julho de 1923, a Turquia e os vencedores da Grande Guerra assinam em Lausanne um tratado que revoga e substitui o precedente tratado de paz, assinado em Sèvres, em 10 de agosto de 1920, pelos representantes do sultão. Sem esperar a implementação do Tratado de Sèvres, que desmembrou a Turquia otomana em favor de seus vizinhos e das minorias, os gregos invadiram no início de 1921 a Anatólia com a aprovação tácita dos Aliados. (ZAGNI, 2013, p. 133). No entanto, foram derrotados. Não obstante, os gregos conseguiram empurrar as forças nacionais turcas para além do Sakarya, um rio que desemboca no mar de Mármara. Com poderes ditatoriais, Mustafah Kemal os detém ao sul do Sakarya em agosto de 1921 após uma longa batalha de três semanas. Completa seu êxito com uma vitória em Dumlupinar em 30 de agosto de 1922. As tropas gregas refluem para o mar Egeu. (ZAGNI, 2013, p. 133).

Em 11 de setembro de 1922, deixam Smirna desordenadamente, arrastando com elas as populações civis. A famosa metrópole da Grécia asiática foi então incendiada. Por força de sua vitória sobre os gregos, Kemal força os Aliados a concluir um novo tratado com a Turquia, substituindo o Tratado de Sèvres. Em virtude do Tratado de Lausanne, os turcos recuperaram a plena soberania sobre os estreitos de Bósforo e Dardanelos, sobre Istambul e seu território europeu, bem como a Armênia Ocidental, o Curdistão Ocidental e a costa oriental do mar Egeu (cidades como Smirna e Éfeso). Além disso, a fronteira com o Iraque é traçada de maneira velada para ser confirmada três anos mais tarde pela Sociedade das Nações, que outorgou a título definitivo a região do Mossul ao Iraque. (ZAGNI, 2013, p. 133).

As Capitulações - estabelecidas em 1536 entre o sultão Soliman, o Magnífico e o rei da França François I e mais tarde estendidas a outros países europeus - são abolidas. Estas convenções outorgavam aos Ocidentais direitos especiais na Turquia, bem como o direito de velar pela sorte dos cristãos desse país. (ZAGNI, 2013, p. 133).

A Turquia moderna emerge das negociações de Lausanne sob a forma de um quadrilátero onde somente o canto noroeste, com Istambul e seus arredores, pertenceriam ao continente europeu (3\% da superfície do país). Expulsos pela ofensiva turca de 1922, 1,3 milhão de gregos ortodoxos estabelecidos na Anatólia desde a Alta Antiguidade atravessariam precipitadamente o mar Egeu para serem recolhidos pela Grécia. Em contrapartida, a Grécia expulsa 300 mil turcos ou gregos islamizados. (ZAGNI, 2013, p. 133).

A república laica de Kemal contava apenas com um punhado de cristãos que, dez anos antes, representavam de um quinto a um décimo da população turca. Inaugurando a prática de "limpezas étnicas", a Turquia de Kemal Atatürk abre as portas aos nacionalismos totalitários: um Estado, uma terra, uma religião, uma língua, uma raça. 
Essas limpezas étnicas parecem ter sido legitimadas, pela primeira vez, pelo Tratado de Lausanne de 23 de julho de 1923. (ZAGNI, 2013, p. 137).

O Tratado de Lausanne, portanto, tinham como especificações:

- Respeito à religião dos grupos minoritários, compatíveis com a moral;

- Liberdade de trânsito de não muçulmanos pelo território do Estado e com capacidade de emigrar, podendo ser frustrada por razões de defesa ou de manutenção da ordem pública;

- Consideração da lei familiar e status pessoal com base nos costumes de não muçulmanos;

- Trabalho conjunto de representantes das minorias com representantes do governo - em caso de divergência, resolução pelo Conselho da Liga das Nações;

- Comprometimento do governo turco em proteger igrejas, sinagogas, cemitérios e demais lugares de relevância religiosa às minorias, bem como de não obstar a criação de novos centros religiosos ou instituições e zelar pelo respeito às religiões minoritárias;

- Garantia de tratamento a minorias muçulmanas na Grécia proporcional.

4. Genocídio Armênio na atualidade e a política turca de negacionismo histórico

Se o Império Otomano foi o perpetrador das matanças dos armênios, é a República da Turquia responsável pelo espólio genocida de seu antecessor. Se não é essa nação a responsável direta pela maior parte das mortes, é a atual república que nega os acontecimentos, compondo assim o último estágio do genocídio: a sua negação. $\mathrm{Na}$ Turquia, a negação é uma política de Estado. Intelectuais são incentivados a publicar estudos que tentam mitigar os acontecimentos de 1915. Fora do país, Ancara faz lobby em universidades espalhadas pelo mundo a fim de conseguir que historiadores e cientistas sociais de renome assinem textos que corroborem a argumentação criminosa. (ZAGNI, 2013, p. 137). A cartilha negacionista é invariável: relativiza números, credita os crimes à insurreição armênia, argumenta que as acusações de genocídio são parte de uma propaganda dos adversários de guerra ou que são motivadas por propósitos econômicos e políticos etc. Os que trabalham em prol da negação distorcem e matam a verdade, última vítima do genocídio. (ZAGNI, 2013, p. 137).

$\mathrm{O}$ art. 301 do Código Penal turco estabelece como crime insultar a dignidade e as instituições da Turquia. (ZAGNI, 2013, p. 137). Esse capcioso mecanismo legal foi usado por muitas vezes para silenciar vozes dissonantes na Turquia que insistiam em afirmar que o genocídio armênio aconteceu. $\mathrm{O}$ genocídio armênio foi fruto das condições 
históricas existentes no momento em que aconteceu. Entretanto, um genocídio tem a capacidade de atravessar a história e permanecer como um espectro que ronda o mundo. Armênios, assírios, judeus, cambojanos, bósnios, tutsis, sudaneses etc. formam uma corrente na qual o último elo está diretamente conectado ao primeiro. Os elementos que tornam os genocídios possíveis continuam se reproduzindo. Os ecos de 1915 reverberam até hoje, seja na disputa diplomática entre Armênia e Turquia, seja em outros massacres em curso no momento. Passado um século do início dos morticínios de armênios, o genocídio armênio permanece atual (ZAGNI, 2013, p. 133), uma vez que permanece em aberto o seu reconhecimento histórico.

O governo da República da Turquia, herdeira legal e cultural do Império Otomano, não reconhece os episódios de 1915 - 1923 como Genocídio. O reconhecimento implicaria em reivindicações armênias, como devolução de terras, pagamento de indenizações, reconstrução e restauração de bens culturais, além dos danos morais causados pelo trauma e pelo desastre social, efeitos diretos do Genocídio. (ZAGNI, 2013, p. 137).

Dessa forma, quase cem anos depois da ocorrência do genocídio, a Turquia e a atual Armênia ainda não chegaram a um consenso sobre o que teria acontecido, razão pela qual a relação entre estes países continua estremecida. Por um lado, a Armênia luta pelo amplo reconhecimento internacional da responsabilidade turca diante da tentativa de exterminar seu povo. Por outro lado, a Turquia nega a ocorrência de um genocídio e julga a tentativa armênia de culpá-los, como forma de denegrir a imagem do governo e reivindicar territórios.

\section{Genocídio no Pós-Guerras Mundiais}

Para Antonio Cassese, crime internacional tem uma dupla dimensão a partir do conceito comum de crime que consiste de dois elementos: a) uma conduta ou actus reus (constituída por um ato ou omissão contrários a uma regra impondo um comportamento específico) e b) um estado mental ou mens rea, um elemento psicológico requerido por lei no qual o autor da conduta pode ser punido. Assim, todo crime internacional é crime na jurisdição doméstica, ou seja, possui os elementos de todo crime (actusreus e mens rea). No entanto, também apresentam uma segunda dimensão, qual seja, a dimensão internacional. Os crimes internacionais violam valores consagrados em tratados ou costume internacional. Logo, um homicídio para ser considerado como crime contra humanidade, ou seja, um crime internacional deve possuir a dimensão doméstica (matar alguém aliado à vontade de matar) adicionado da dimensão internacional (existência de um ataque sistemático à população civil e ciência da existência deste ataque sistemático). (CASSESE, 2008, p. 58). 
O genocídio é caracterizado como crime internacional e é conceituado como a destruição intencional, por meio de uma das cinco categorias específicas de conduta contra um grupo nacional, étnico, racial ou religioso ou contra membros destes grupos. (CASSESE, 2008, p. 127). O termo "genocídio" tal como criado pelo jurista polonês Raphael Lemkin, que também garantiu que o conceito formulado se tornasse amplamente divulgado e reconhecido como um crime cuja repressão e punição estariam amplamente asseguradas no Direito Internacional. A criação do termo, em 1944, ocorreu na sua obra Axis Rule in Occupied Europe (O governo do Eixo na Europa ocupada) pela junção do grego genos ${ }^{5}$ em referência à raça, tribo ou nação com o sufixo cide $^{6}$ derivado do latim cìda (QUIGLEY, 2006, p. 426, tradução pessoal) e refere-se a "aquele que mata" ou "aquele que fere". Lemkin desenvolveu o conceito de genocídio, em parte, devido ao Holocausto, mas também devido a instâncias anteriores em que considerou que nações inteiras, grupos étnicos e religiosos resultaram aniquilados como na Primeira Guerra, o massacre dos armênios.

Conforme Luiz Augusto Módolo, “de 1945 até a década de 1990, houve muito avanço na normatização do Direito Internacional Penal, como o advento da Convenção para a prevenção e repressão do crime de genocídio (1948) e das quatro Convenções de Genebra (1949)". (PAULA, 2014, p. 32).

O crime de genocídio não foi incluído na jurisdição do Tribunal Militar Internacional de Nuremberg muito embora este termo foi usado por vários procuradores. O processamento de tais condutas se deu por meio do crime de exterminação de população civil conforme o art. 6 (c) da Carta de Nuremberg. (O’KEEFE, 2017, p. 146). Em 1946, a Assembleia Geral das Nações Unidas em sua Resolução n. 96 (1) considerou que o genocídio já era crime sob o direito internacional geral, dando assim evidência de uma opinio juris e formando a base do que viria ser a Convenção para a prevenção e repressão do crime de genocídio que foi uma reação ao genocídio nazista e entrou em validade no dia 12 de janeiro de 1951. (GUILFOYLE, 2016, p. 269-270). Ainda naquele ano, a Corte Internacional de Justiça considerou que os princípios da Convenção seriam vinculantes a

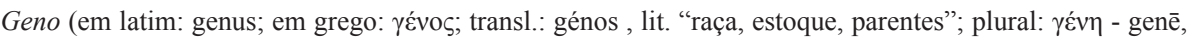
na Grécia Antiga, era um tipo de organização social na qual alguns indivíduos alegavam descendência comum, referindo-se por um nome único (ver sânscrito "Gana"). Muitos genos parecem ter sido compostos de famílias nobres - Heródoto usa o termo para denotar famílias nobres - e muitos dos primeiros políticos gregos parecem ter envolvido-se em lutas entre genos. Hornblower and Spawforth (2011, tradução pessoal).

6 Cide: $\mathrm{m}$-cide (-cide genitivo); primeira declinação; sufixo que denota "aquele que mata" ou "aquele que fere" do tronco substantivo formando-substantivo - verbete: "-cīda". Glare (2012, p. 344, tradução pessoal). 
todos os Estados $^{7}$ e em casos posteriores considerou que a proibição ao genocídio seria uma norma peremptória de Direito Internacional - jus cogens. ${ }^{8}$

A Convenção para prevenção e repressão do crime de genocídio foi promulgada pelo Decreto n. 30.822, de 6 de maio de 1952. Seu segundo artigo traz o conceito positivado de genocídio:

Na presente Convenção entende-se por genocídio qualquer dos seguintes atos, cometidos com a intenção de destruir no todo ou em parte, um grupo nacional, étnico, racial ou religioso, como tal:

a) matar membros do grupo;

b) causar lesão grave à integridade física ou mental de membros do grupo;

c) submeter intencionalmente o grupo a condições de existência capazes de ocasionar-lhe a destruição física total ou parcial;

d) adotar medidas destinadas a impedir os nascimentos no seio de grupo;

e) efetuar a transferência forçada de crianças do grupo para outro grupo. (BRASIL, 1952).

AConvenção avança para dispor que não somente aqueles que se encarregam de fisicamente executar o genocídio são responsáveis pelo mesmo como também aqueles descritos no art. $3^{\circ}$ da Convenção:

Serão punidos os seguintes atos:

a) o genocídio;

b) a associação de pessoas para cometer o genocídio;

c) a incitação direta e pública a cometer o genocídio;

d) a tentativa de genocídio;

e) a coautoria no genocídio. (BRASIL, 1952).

7 INTERNATIONAL COURT OF JUSTICE. Reports of judgments, advisory opinions and orders. Reservations to the convention on the prevention and punishment of the crime of genocide. Leyden: A. W. Sijthoff's, 1951. Disponível em: <https://www.icj-cij.org/files/case-related/12/012-19510528-ADV-01-00EN.pdf $>$.

8 INTERNATIONAL COURT OF JUSTICE. Reports of judgments, advisory opinions and orders. Case concerning armed activities on the territory of the Congo (New application: 2002). (Democratic Republic of the Congo v. Rwanda). Feb. 2006. § 64. Disponível em: <https://www.icj-cij.org/files/case-related/126/12620060203-JUD-01-00-EN.pdf>; INTERNATIONAL COURT OF JUSTICE. Reports of judgments, advisory opinions and orders. Case concerning application of the convention on the prevention and punishment of the crime of genocide (Bosnia and Herzegovina v. Serbia and Montenegro). Feb. 2017. § 161. Disponível em: <https://www.icj-cij.org/files/case-related/91/091-20070226-JUD-01-00-EN.pdf>. 
Assim, algumas conclusões podem ser extraídas da leitura destes artigos nucleares conforme a análise de Douglas Guilfoyle:

a) O Crime de genocídio é praticado contra membros de grupos protegidos (nacional. étnico, racial ou religioso) mas a convenção não define estes termos. É necessário que estes termos sejam considerados em conjunto com o contexto político, social e cultural para que sejam definidos;

b) A lista de grupos protegidos é exaustiva e não pode ser interpretada para alcançar outros grupos (exemplo: membros de um partido político);

c) A lista de condutas proibidas não está limitada ao homicídio mas não inclui expressamente esforços para mudar a identidade cultural de um grupo (o genocídio cultural);

d) Os atos proibidos devem ser acompanhados pela intenção de destruir no todo ou em parte o grupo protegido e o agente deve ter esta intenção. (BRASIL, 1952).

A Convenção não inclui entre os requisitos para a comissão do genocídio que tais atos sejam cometidos como parte de uma política governamental como ocorre nos crimes contra humanidade. (GUILFOYLE, 2016, p. 271). No entanto, é a presença de uma política de Estado é evidência importante para que se prove o genocídio principalmente para provar o elemento subjetivo de um agente individual. Muito embora, o Tribunal da Iugoslávia já considerou a possibilidade de um agente individual ter a intenção de destruir um grupo no todo ou em parte. ${ }^{9}$ Ademais, não é necessário que o agente queria destruir o grupo em todo canto do globo, alguma restrição geográfica é permitida. No entanto, a destruição de uma cidade apenas deve ser representativa de todo o grupo. ${ }^{10}$

\section{Conclusão}

Este trabalho procurou expor como "o grande crime"11 contra os armênios ocorreu, do ponto de vista histórico, e posteriormente analisar atos políticos e de Direito Internacional Público decorrentes dele e da Primeira Guerra Mundial para, por fim,

9 UNITED NATION. International Criminal Tribunal for the former Yugoslavia (ICTY). In the trial chamber: the prosecutor v. Goran Jelisić. Haia, Dec. 1999. Disponível em: <http://www.icty.org/x/cases/jelisic/tjug/ en/jel-tj991214e.pdf>.

10 UNITED NATION. International Criminal Tribunal for the former Yugoslavia (ICTY). In the trial chamber: prosecutor v. Radislav Krstić. Haia, Aug. 2001. Disponível em: <http://www.icty.org/x/cases/krstic/tjug/en/ krs-tj010802e.pdf>.

11 A expressão em língua armênia "Medz Yeghern" (Uţ̇ Enţnq) significa "Grande Crime", é uma forma recorrente com a qual os armênios se referem ao genocídio. 
demonstrar como o genocídio passou a ser considerado juridicamente a partir do Século XX levando-se em consideração as tragédias do episódio armênio até o edifício jurídicoinstitucional criado a partir da Segunda Guerra Mundial. De modo geral podemos verificar que a história da humanidade exemplificada pelo Genocídio Armênio é pontuada de macrotragédias que moldam as instituições. De maneira similar (e talvez mais divulgado mas não menos trágico), o Holocausto imposto pelo regime nazista foi outro exemplo de acontecimento histórico que reforçou a necessidade de maior intervenção da comunidade internacional. No entanto, apenas com o fortalecimento de estruturas destinadas a este amparo podemos falar em maior proteção à pessoa humana na seara internacional.

O amparo passa também por maior aparelhamento dos órgãos investidos da governança global para que possam coibir com efetividade eventuais tragédias como o genocídio armênio e o holocausto nazista. Observa-se que a relação da governança global com a esfera doméstica é de interdependência, visto que as duas esferas são mutuamente complementares. Assim, efetividade do sistema internacional depende das ações tomadas na esfera doméstica em cada Estado. Por outro lado, os Estados desejam ser atores importantes na seara global e para tanto necessitam se comprometer em todas as esferas da política internacional.

O direito pode ser uma técnica de regulação da sociedade que age conforme fins determinados pela política, isto é, frente ao modelo político, o direito deve responder a uma dinâmica que esse meio cria, de modo que o mero estabelecimento do instituto do genocídio não deve ser um fim em si mesmo, uma vez que se procura com ele, não só prevenir novos acontecimentos dessa natureza, mas também promover possível responsabilização internacional, identificando os agentes causadores e promovendo a reparação das vítimas, o que passa pela aferição da extensão do dano, entre outros fatores.

Os impactos experimentados pela civilização armênia em decorrência do genocídio são imensuráveis. Sua população foi dizimada, trazendo um abalo demográfico expresso até os dias atuais, em que o país conta com população pouco superior a do ano de 1915 (ARMENIAN, 2017). A morte de intelectuais e destruição de seus locais sagrados e históricos traz uma perda cultural inestimável para esta civilização que há milênios despontava por sua erudição e por sua singularidade cultural. E, claro, os impactos econômicos: por mais que hoje, em geral, os descendentes armênios espalhados pelo mundo ${ }^{12}$ ocupem posições economicamente confortáveis, o país teve perdas territoriais

12 KÉVORKIAN, Raymond Haroutin; DUCLERT, Vincent; BOZARSLAN, Hamit. Comprende le génocide des arméniens: 1915 à nos jours. Paris: Éditions Tallandier, 2015. p. 14: “On estime aujourd'hui à prés de 7 millions le nombre d'Arméniens dans le monde. Ils se répartissent entre la République D'Arménie (3 millions), d'une part et la diaspora de l'autre, dont les principaux foyers sont les États-Units (1,3 millions), l'ex URSS(1,5 million), la France (400 000) et le Moyen-Orient (310 000), etc. Il ne sont plus que 50000 en Turquie, principalement à Istanbul”. 
(de recursos e acesso ao mar) e em seu desenvolvimento econômico que, entre outros fatores, fazem com que boa parte de sua população no país seja, atualmente, rural, com uma economia altamente dependente da importação de produtos (sobretudo da Rússia), o que eleva os preços e restringe o consumo. A oferta de empregos faz com que um elevado contingente populacional, sobretudo homens jovens, emigre sazonalmente ou por períodos prolongados para trabalhar fora do país, principalmente na Rússia, o que resulta em um número elevado de vilarejos em que habitam apenas mulheres, crianças e idosos. O país sofre ainda com a "fuga de cérebros" e seu desenvolvimento demográfico foi negativo entre os anos de 1990 e 2010.

A maior cicatriz que o povo armênio tem cravada, porém, diz respeito à sua honra e memória. $\mathrm{O}$ episódio mais marcante de sua história não é amplamente reconhecido. A Turquia, como já exposto, nega a existência nos termos em que a robusta reconstituição histórica internacional converge e, não só aplica medidas para evitar que a questão ganhe notoriedade, como tenta impor sua versão sobre o ocorrido, que é, por óbvio, mais branda e vestida de justificativas que tentam eximi-la da culpa. ${ }^{13}$ Ainda, joga com seu poderio econômico, impondo sanções diplomáticas e comerciais a países que reconhecem a ocorrência do massacre. Infelizmente, o interesse financeiro, recorrentemente prevalece sobre a dignidade humana, o que faz com que o reconhecimento por países que têm relações com a Turquia, como Brasil, Estados Unidos, Israel, entre outros, não ocorra. Atualmente, apenas 23 nações reconhecem o Genocídio Armênio, ${ }^{14}$ considerando dentre essas o País Basco e Curdistão.

Nas palavras do Prof. Dr. Paulo Borba Casella, "o problema do Genocídio Armênio é que ninguém fala dele", o que permite, por fim, concluir que a academia pode desempenhar importante papel abordando e divulgando o tema, e endossando o movimento político para que haja amplo reconhecimento, inclusive por meio da formação de profissionais devidamente sensibilizados à questão, além de, por meio da pesquisa nas diversas áreas, que não só do direito, agregar evidências que tornem cada vez mais robustas as já extensas e inegáveis provas de seu acontecimento, enfraquecendo assim o movimento negacionista e a invisibilidade do assunto.

São Paulo, abril de 2018.

\footnotetext{
13 Ancara admite as mortes de até 500 mil armênios numa "guerra civil" entre 1915 e 1917.

14 PAÍSES que reconhecem o genocídio Armênio. Genocídio Armênio. Disponível em: <http:// genocidioarmenio.com.br/historia/quem-reconhece/>. Acesso em: 20 jun. 2017.
} 


\section{Referências}

ADALIAN, Rouben Paul. Adana Massacre. In: ENCYCLOPEDIA Entries on the Armenian Genocide. Armenian National Institute. Washington - DC, 2005. Disponível em: <http://www. armenian-genocide.org/adana.html>. Acesso em: 23 jun. 2017.

ARMENIAN population. BBC News, [London], 2017. Disponível em: <http://www.bbc.com/news/ world-europe-17398605>. Acesso em: 26 jun. 2017.

BAGHDJIAN, Kévork, K. La confiscation, par le gouvernement turc, des biens arméniens dits “abandonnés”. Préface Yves Ternon. Saint-Lambert: Payette \& Simms, Inc., 1987.

BRASIL. Decreto n. 30.822, de 6 de maio de 1952. Promulga a Convenção para a Prevenção e a Repressão do Crime de Genocídio, concluída em Paris, a 11 de dezembro de 1948, por ocasião da III Sessão da Assembléia Geral das Nações Unidas. Portal da Câmara dos Deputados, Brasília, DF, 1952. <http://www2.camara.leg.br/legin/fed/decret/1950-1959/decreto-30822-6-maio-1952339476-publicacaooriginal-1-pe.html>. Acesso em: 12 maio 2018.

BRYCE, James. Introduction. In: TOYNBEE, Arnold Joseph. Les massacres des armeniéns: le meurtre d'une nation, 1915-1916. Paris: Payot, 1987.

CASELLA, Paulo Borba. O genocídio armênio. In: ROCHA, Maria Elizabeth Guimarães Teixeira. (Org.). CICCO FILHO, Alceu José; VELLOSO, Ana Flávia Penna. (Coord.). Direito internacional na constituição: estudos em homenagem a Francisco Rezek. São Paulo: Saraiva, 2014.

CASSESE, Antonio. International criminal law. 2. ed. Oxford, New York: Oxford University Press, 2008.

GLARE, P. G. W. (Ed.). -cide. In: . The Oxford latin dictionary. Oxford: Oxford, New York: Oxford University Press, 2012.

GUILFOYLE, Douglas. International criminal law. Oxford, New York: Oxford University Press, 2016.

HORNBLOWER, Simon; SPAWFORTH, Anthony. Geno. In: ; . The Oxford classical dictionary. Oxford, New York: Oxford University Press, 2011.

INTERNATIONAL COURT OF JUSTICE. Reports of judgments, advisory opinions and orders. Case concerning armed activities on the territory of the Congo (New application: 2002). (Democratic Republic of the Congo v. Rwanda). Feb. 2006. § 64. Disponível em: $<$ https://www.icj-cij.org/files/ case-related/126/126-20060203-JUD-01-00-EN.pdf>.

INTERNATIONAL COURT OF JUSTICE. Reports of judgments, advisory opinions and orders. Case concerning application of the convention on the prevention and punishment of the crime of genocide (Bosnia and Herzegovina v. Serbia and Montenegro). Feb. 2017. § 161. Disponível em: $<$ https://www.icj-cij.org/files/case-related/91/091-20070226-JUD-01-00-EN.pdf>. 
KÉVORKIAN, Raymond Haroutin; DUCLERT, Vincent; BOZARSLAN, Hamit. Comprende le génocide des arméniens: 1915 à nos jours. Paris: Éditions Tallandier, 2015.

LAUSANNE Traité de (1923). In: ENCYCLOPAEDIA Universalis. Disponível em: <http://www. universalis.fr/encyclopedie/traite-de-lausanne/>. Acesso em: 18 jun. 2017.

O'KEEFE, Roger. International Criminal Law. Oxford: Oxford University Press, 2017. (The Oxford International Law Library).

PAÍSES que reconhecem o genocídio Armênio. Genocídio Armênio. Disponível em: <http:// genocidioarmenio.com.br/historia/quem-reconhece/>. Acesso em: 20 jun. 2017.

PAULA, Luiz Augusto Módolo de. Genocídio e o tribunal penal internacional para Ruanda. Curitiba: Appris, 2014.

QUIGLEY, John Bernard. The Genocide Convention: an international law analysis. New York: Routledge, July 2006.

SÈVRES Traité de (10 août 1920). In: ENCYCLOPAEDIA Universalis. Disponível em: <http:// www.universalis.fr/encyclopedie/traite-de-sevres/>. Acesso em: 18 jun. 2017.

TREATIES of Brest-Litovsk. In: ENCYCLOPAEDIA Britannica. 1918. Disponível em: <https:// www.britannica.com/topic/treaties-of-Brest-Litovsk>. Acesso em: 18 jun. 2017.

UNITED NATION. International Criminal Tribunal for the former Yugoslavia (ICTY). In the trial chamber: the prosecutor v. Goran Jelisić. Haia, Dec. 1999. Disponível em: <http://www.icty.org/x/ cases/jelisic/tjug/en/jel-tj991214e.pdf>.

UNITED NATION. International Criminal Tribunal for the former Yugoslavia (ICTY). In the trial chamber: prosecutor v. Radislav Krstić. Haia, Aug. 2001. Disponível em: <http://www.icty.org/x/ cases/krstic/tjug/en/krs-tj010802e.pdf>.

ZAGNI, Rodrigo Medina; BORELLI, Andrea. (Org.). Conflitos armados, massacres e genocídios: constituição e violações do direito à existência na era contemporânea. Belo Horizonte: Fino Traço, 2013. 